\title{
LOESS-SCAPE IN THE DOBRUDJA PLATEAU (ROMANIA). LANDFORMS AND UPDATED TYPOLOGY
}

\section{Gheorghe Romanescu ${ }^{1}$, Denes Lóczy ${ }^{2}$, József Dezső ${ }^{2}$, Donatella Carboni $^{3}$}

Keywords: border dynamics; loess-like deposits; piping; set of factors; typology

\begin{abstract}
The study of loess and loess-like deposits in Romania has developed considerably, over the years. C14 dating determined that the last three glaciations (Mindel, Riss, Würm) and, at least, two interglacial periods were recorded in the Dobrudja Plateau. Five other paleosol layers indicate the succession of the Quaternary interglacial stations. The loess of Dobrudja, is about $50 \mathrm{~m}$ in thickness. The term loess-scape is comprised of all the processes and forms specific to these deposits, which create a unique landscape, with local peculiarities. Natural and anthropic conditions created loessoid microforms (clastokarst) specific to the Dobrudja Plateau. The friability of loess-like deposits, the heavy rains, the lack of vegetation, the existence of a steep slope and of a low basic level, led to the development of a marginal (border) clastokarst on the western and northern side of the plateau (on the right of Danube bank). The aim of this study is to rename the microforms specific to loess-like deposits and to highlight new ones: solution clastic dolines, collapse clastic dolines, clastic resurgences (intermittent karst springs), piping clastic glacis, collapse clastic glacis, proluvial clastic glacis, clastic micro-waterfalls with clastic micro-cauldrons, clastokarstic curtains (drapes), and so on. Consequently, the loess-scape in the Dobrudja Plateau is distinct, just like the karstic, volcanic, glacial landscape, and so on. New clastokarstic microforms were highlighted and efforts were made to establish a proper terminology.
\end{abstract}

\footnotetext{
${ }^{1}$ Alexandru Ioan Cuza University, Iasi, Faculty of Geography and Geology, Department of Geography, Iasi, Romania, e-mail: romanescugheorghe@gmail.com ${ }^{2}$ Institute of Geography, Faculty of Sciences, University of Pécs, Ifjúság útja 6. H-7624 Pécs, Hungary

${ }^{3}$ Università degli Studi di Sassari, Dipartimento di Scienze Umanistiche e Sociali, Via Roma, 151, 07100, Sassari, Italy
} 


\section{Introduction}

The popularity gained by loess in Romania has led to detailed studies, which have been conducted in different historical periods. Most studies conducted before the year 2000 (and rarely after this year), were based on general geologic or pedologic observations, or descriptive geomorphological information (Florea, 2010). Romania's adherence to the European Union has revived top research, mostly those related to dating. Most studies of this type were conducted after the year 2009, when it became possible to date the samples within Romanian laboratories (Balescu et al., 2010; Constantin et al., 2013; Ghenea and Radan, 1993; Necula et al., 2015; Radan et al., 1990; Radan, 2012). Internationally, various studies were conducted in all continents, and mostly in Asia ( $\mathrm{Li}$ et al., 2015, 2016; Su et al., 2017), Europa (Antonov, 2003; Buggle et al., 2009; Castillo and Gómez, 2016; Jordanova and Petersen, 1999; Jordanova et al., 2007) and America (Kuzila, 1995; Muhs et al., 2004).

The most important part of this study is related to the genesis of the relief and the typology of certain landforms that have not been studied in details or included within the classical typology. This is actually the objective of this study, which includes examples for loess-specific piping forms in Dobrudja (Romania). In order to highlight relief specificities in Dobrudja, it was necessary to consult an abundant scientific literature on the genesis and typology of piping and loess-specific landforms, and of loess-like deposits all over the world and in Romania, implicitly (Cotet, 1969; Leger, 1990; Pye, 1996; Romanescu, 1995; Rozycki, 1967; Tufescu, 1966; Wang et al., 2011; Zhongchen and Baoyin, 1995; Zhu et al., 2002). Landforms specific to Dobrudja were renamed and explained from a genetic perspective.

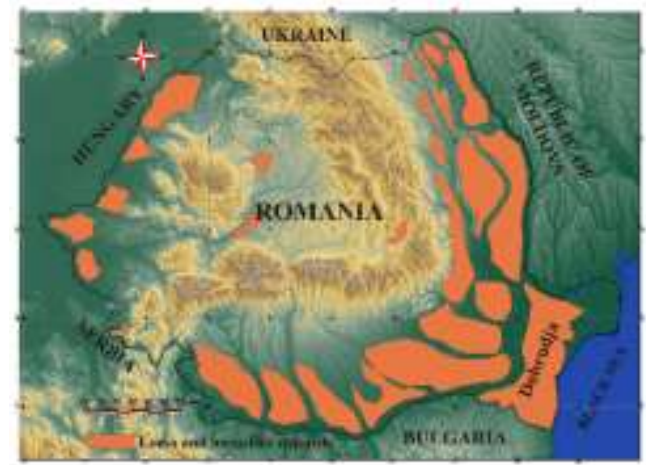

Fig. 1 - Loess and loess-like deposits in Romania 


\section{Regional setting}

The Dobrudja Plateau is situated in the northeast of Romania; it is limited to the west and north by the Danube River, to the northeast by the Danube Delta and the Razim-Sinoe lagoon complex, to the east by the Black Sea, and to the south by the border with Bulgaria. It is a huge horst, which comprises of the old massif of the Macin Mountains (Palaeozoic) and the Tulcea Hills (Triassic) in the north, the Casimcei plateau (Precambrian) in the centre, and the Southern Dobrudja Plateau (Meso-Cretaceus) in the south. Most of Dobrudja - except for the Danube Delta is covered by a thick layer of loess and loess-like deposits, some of which are even $50 \mathrm{~m}$ thick (Romanescu, 2013, 2014). Loess and loess-like deposits in Romania are also present in the Romanian Plain (south), and the Moldavian Plateau (east) (Fig. 1). The Dobrudja Plateau is crossed in the centre by the parallel of latitude $44^{\circ} 84^{\prime}$ north and by the meridian of longitude $28^{\circ} 49^{\prime}$ east.

\section{Materials and methods}

National and international bibliographic materials that have studied the genesis of loess and derived landforms, were consulted. Field research covered the entire region of the Dobrudja Plateau and the areas belonging to the Romanian Plain and to the Moldavian Plateau. Detailed observations focused on the western and northern sectors of Dobrudja, where the deposits were the thickest, and where the slopes were elevated (Danubian terrace abrupt). The research was conducted in the period, 2005-2015. Such a long interval was needed because comparisons were made with other regions on Earth (also using field research): China, Ukraine, Hungary, the USA, Russia, Argentina, Poland, Italy, France, and so on.

Micro-landforms were measured using a ruler and located through GPS Leica 1200 System. Larger landforms were measured using the Total Stations and on orthophotoplans $(2010,2015)$. For measurements of the morphometric parameters, the Leica 3-D scanner was used.

\section{Results and discussions}

\section{Origin of loess}

From a structural perspective, Dobrudja is divided into three morpho-tectonic units: Northern Dobrudja, Central Dobrudja, and Southern Dobrudja. The three sectors are separated by the Peceneaga-Camena and the Capidava-Ovidiu faults (Ionesi, 1994; Romanescu, 1995; Romanescu et al., 2014, 2015).

Quaternary covered older formations. On top of the Sarmatian or older limestones, there were greenish and reddish clays and silts, with calcareous concretions or gypsum crystals and crystal aggregates (locally). These deposits represent residual alteration products (paleosols), formed on land, but the presence of gypsum shows that, at least, this material accumulated in marshy areas. They are 
5-m thick and are covered by loess-like deposits up to $50 \mathrm{~m}$ thickness, which also comprised 2-7 brick-coloured and more clayey layers, represented by paleosols (Cotet, 1969; Florea, 2010; Lacatusu et al., 2010; Tufescu, 1966) (Table 1). Loesslike deposits also included traces of Mammuthus primigenius, and Coelodonta antiquitatis. Loess was mostly, but not exclusively aeolian, and it accumulated in the glacial periods or stages of the Quaternary. It is based on the alluvial depositions that were reshaped by the wind (Florea, 2010; Tufescu, 1966).

Table 1 - Loess characteristics of Dobrudja (after Frincu and Dumitrache 2014; Lacatusu et al. 2010; acinetnathaz.net/wp-content/uploads/2015/12/LHA-Tessaloniki-May-2015Carmen-P4.pdf)

\begin{tabular}{|c|c|c|c|c|c|c|}
\hline \multirow[t]{2}{*}{$\begin{array}{l}\text { Origin of the } \\
\text { loess }\end{array}$} & \multirow[t]{2}{*}{$\begin{array}{l}\text { Thickness } \\
\text { of the loess }\end{array}$} & \multirow[t]{2}{*}{$\begin{array}{l}\text { High } \\
\text { porosity }\end{array}$} & \multirow[t]{2}{*}{$\begin{array}{c}\text { Types of loess and loess } \\
\text { deposits }\end{array}$} & \multicolumn{3}{|c|}{$\begin{array}{l}\text { Medium total and mobile } \\
\text { selenium content }(\mu \mathrm{g} \cdot \mathrm{kg}-1) \text { in } \\
\text { rocks and parental materials on } \\
\text { which the soil formed in } \\
\text { Dobrodja }\end{array}$} \\
\hline & & & & & $\begin{array}{c}\text { Total } \\
\text { Se }\end{array}$ & $\begin{array}{l}\text { Mobile } \\
\text { Se }\end{array}$ \\
\hline $\begin{array}{c}\text { Typical loess } \\
\text { with paleosoils } \\
\text { on interfluve } \\
\text { aeolian origin } \\
\text { on southern } \\
\text { interfluves, }\end{array}$ & $\begin{array}{c}\text {-Ostrov - } \\
30 \mathrm{~m} \\
\text {-Cernavoda- } \\
\text { Borcea - }\end{array}$ & $40-50 \%$ & $\begin{array}{l}\text {-Sandy-silty loess and } \\
\text { loess-like deposits (v); } \\
\text {-Sandy-silty loess and } \\
\text { loess-like deposits, silty in } \\
\text { the upper past of the beds; } \\
\text {-Silty loess and loess-like }\end{array}$ & $\begin{array}{c}\text { Central } \\
\text { Dobrudja }\end{array}$ & $100 \pm 15$ & $4.6 \pm 0.5$ \\
\hline $\begin{array}{l}\text { deluvial } \\
\text { aeolian a slopes } \\
\text { in north and } \\
\text { center and } \\
\text { aluvial-deluvial } \\
\text { on terraces }\end{array}$ & $\begin{array}{c}40-60 \mathrm{~m} \\
\text {-Constanta- } \\
6-10 \mathrm{~m}\end{array}$ & & $\begin{array}{l}\text { deposits; } \\
\text {-Silty loess and loess-like } \\
\text { deposits (silty-clayey in } \\
\text { the upper part of the beds); } \\
\text {-Silty-clayey loess and } \\
\text { loess-like deposits. }\end{array}$ & $\begin{array}{l}\text { Southern } \\
\text { Dobrudja }\end{array}$ & $84 \pm 18$ & $4.8 \pm 1.3$ \\
\hline
\end{tabular}

The lower Danube basin comprised of two distinct types of loess and loesslike deposits: silty-clayey sediments; silty-clayey sediments associated with coarser-groined clastics. The most common deposit was the silty-clayey one. From a textural perspective, three facies were distinguished: coarse-grained loess; regular loess; loess-like. Of the four European glaciations (Günz 1200000-70000 BP; Mindel 650000-350000 BP; Riss 300000-120000 BP; Würm 80000-15000 BP), only three of them occurred on the Romanian territory. This was also proven by the existence of loess deposited around 700,000 years BP for the first time (Balescu et al., 2010; Buggle et al., 2009; Radan et al., 1990).

At the base of the loess (or at the beginning of the Quaternary), there were some deposits known as red clays or residual-eluvial deposits. Reddish eluvia are usually located underneath the loess and on various pre-Quaternary formations. Their creation is ascribed to the various continental phases when relief was subjected to a peneplanation process (Romanescu, 2013; Romanescu and Cojocaru, 
2010; Romanescu et al., 2015). The red colour reflects the paleo-climatic conditions experienced by a relief throughout its evolution. Their estimated age is Villafranchian, but they could be even older from Pliocene, for instance.

The most interesting deposits in terms of the influence on the current landforms, were represented by loess and loess-like deposits. While loess-like deposits seemed evenly distributed, resulting landforms were diversified and in certain points older - pre-Quaternary - rocks emerged at the surface. Fossil soils were brought to the surface by erosion, mostly on the slopes of the main valleys and even on crests. Loess did not feature the same characteristics on the entire thickness of the layer or on the entire distribution of the surface area. Important variations in texture, carbonate content, layer thickness, or their vertical succession were recorded.

The origin of loess is not the same on its entire surface or thickness. For this reason, it is understandable that relief cannot be uniform, mostly when it comes to the microforms specific to the loess-like deposit (Florea, 2010; Tufescu, 1966). A typical loess is defined as an unconsolidated, mobile rock, formed in the Quaternary due to the aeolian action during the glacial periods or stages (Muhs et al., 2004). It features the following characteristics:

-Mechanical composition is rather homogeneous; particles ranging between 0.05-0.01 $\mathrm{mm}(>50 \%)$ dominate; coarse fraction $(>0.2 \mathrm{~mm})$ absent or insignificantly present. Clay $(<0.002 \mathrm{~mm})$ may represent $10 \%-15 \%$ in Germany or $15 \%-30 \%$ in Romania (Conea, 1970);

-The lack of obvious stratification, though the phenomenon is obvious for most deposits;

-High porosity: $45 \%-50 \%$ or even $65 \%$ (pores are tabular);

-Breaking on vertical sides;

-Usually yellow (10 YR) but also featuring a slight red hue;

-It contains carbonates, mostly of $\mathrm{Ca}(15 \%-25 \%, 20 \%$, and $10 \%-30 \%)$;

-In terms of mineralogy, quartz $(60 \%-70 \%)$ is dominant, followed by feldspar, mica, and so on.

The Dobrudja Plateau loess has the form of thick deposits or of a sediment nappe and it is often present on interfluves. It has good permeability. When dry it is easy to break it by pressing it between the fingers. In optimal conditions, settlement processes develop on the loess, entailing an abundance of clastic dolines on the flat surfaces. It erodes easily. Carbonates are evenly distributed in the rock mass (primary carbonates), but also accumulated as concretions (loess dolls), small veins (secondary carbonates) and so on. It changes and cements difficultly (Tufescu, 1966).

The colours of the loess-like deposits are different from those of a typical loess (yellow, reddish, brown, gray, and so on), and their variable porosity, and 
obvious stratification are also different. Granulometric composition varied: from clayey sand to clay, generally, with low amounts of dust and higher amounts of clay, with coarse sands and even gravels. They are less broken up and they become plastic; they are no longer porous and their sinkholes are not characteristic, because they turn into small depressions. Their colour changes and becomes darker or redder. The increase in the sand percentage alters the characteristics of the rock. In this case, the material breaks up more easily and it has a higher capacity for air because it lacks plasticity. Piping micro-landforms are scarce. Carbonates are unevenly distributed and their percentage is lower than that of the typical loess.

Loess and loess-like deposits are comprised of, first of all, the lithologic formation, and not the genetic formation (Conea, 1970). In Dobrudja, loess and loess-like deposits are $50 \mathrm{~m}$ thick. Loess and loess-like deposits in Dobrudja featured the following characteristics:

-Great thickness of deposits, with a reduction in the WNW-ESE direction, mainly from the Danube, towards the Black Sea;

-The existence of 2-3 bands of buried soils (a maximum of 7) reflects two types of soil formation: steppe; forest;

-Interglacial soils belonging to the forest type; they were created in a slightly warmer climate than the one of Europe, but also more humid than the current climate of Dobrudja. There were also Würmian interstadial soils;

-Chernozems and forest soils associated and formed groups of soils;

-All types of loess - except for certain local formations - are carbonatic $(15 \%$ $20 \% \mathrm{CO}_{3} \mathrm{Ca}$ on average). This character shows the existence of a dry climate during their deposition. The oldest types of loess dates back to the Mindel, and they seem to have deposited under conditions of mitigated dryness;

-The loess layers, like fossil soils, were affected by erosive processes (the material was set in motion by water flowing from rain and snow), and re-deposited either on slopes or in valleys;

-Upper Pleistocene is represented by thick layers of loess, and by pedologic formations similar to the ones of the last interglacial;

-The main soil within Riss-Würm interglacial is different from the current one;

-There are no paleopedologic or lithologic formations to indicate very cold or very humid climates;

-Periglacial forms specifically to cold and humid climates are not characteristic of this area (Conea, 1970; Tufescu, 1966). The constitution and character of loess layers in Dobrudja, is conditioned by the intensity and manifestation of the relief modelling manifestations. Aeolian loess features a uniform disposition of particles and a finer texture. On these deposits, settling processes are weak. In the sectors with reshaped loess, the material's non- 
uniformity favours the development of differentiated erosion phenomena, which are locally very intense.

As a consequence of the aeolian origin, it is worth highlighting that the loess deposits in Dobrudja presented a general NNW-SSE orientation, in agreement with the general wind direction at the moment of deposition (namely the glacial periods). On the Bulgarian territory, south from Dobrudja, alignments continued until the disappearance line. West from this alignment, the same units of loess could be found, but this time, they had a West-East (W-E) direction. It is also worth noting that there was a change in the composition of the loess in Dobrudja and the one in the centre and west of Bulgaria. The material carried by the wind on short distances determined a change in the facies of the Dobrudjan loess, because it entailed a significantly higher amount of sand, which actually explains the existence of loess-like deposits (Antonov, 2003; Jordanova and Peterson, 1999; Jordanova et al., 2007; Rozycki, 1967).

Fluviolacustrine deposits appear either as fine, marshy deposits, of dusts, clayey sands or sandy clays (loessified), known as loess-like deposits, or coarse deposits (psamo-psephitic). In the same category of coarse fluviolacustrine deposits, one may include those of the Romanian (Levantine) terrace on the Danubian side, unfolding between Ostrov and Rasova. Holocene fluvial deposits are represented by sands and sandy clays up to $5 \mathrm{~m}-8 \mathrm{~m}$ thick, and so on.

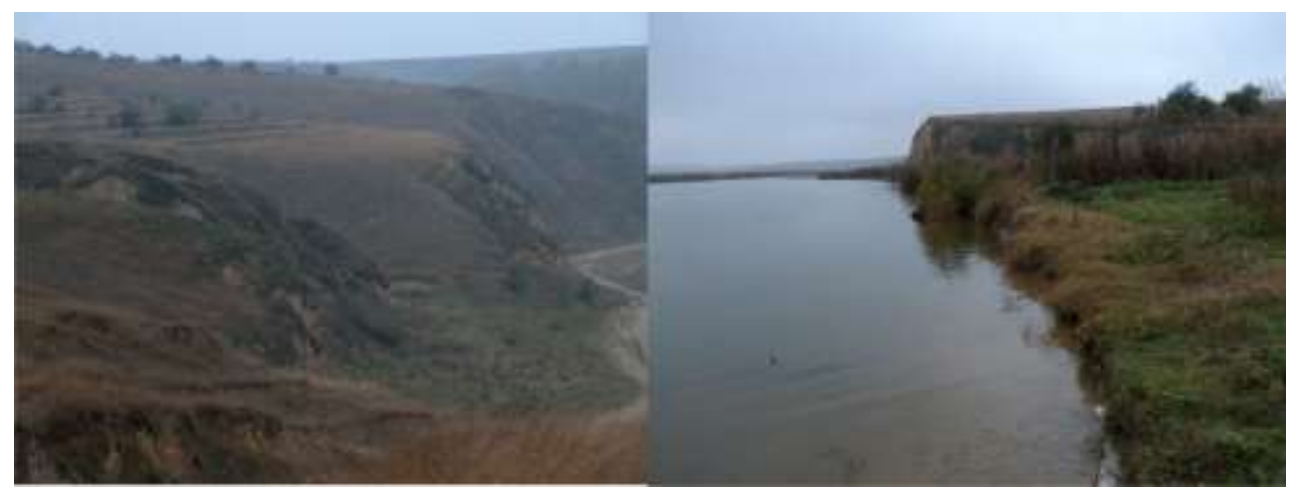

Fig 2 - Border (marginal) modelling and Danube loessoid terrace (Ostrov-Oltina)

During the Quaternary, the hydrographical network was finalized and the previous relief was covered by loess; fluvial and lacustrine terraces were formed, and the karst formation extended. The geomorphological importance of Dobrudja is provided by several key factors (Cotet, 1969). The west and north of Dobrudja, represents a well-individualized geographic subunit, with a particular physico- 
geographic structure. It is highlighted by high energy and a significant degree of relief fragmentation, not only by the type of relief, but also by the morpholithology. The originality consists in the influence exerted by the Danube, the Ialomiţa Polder, and the Braila Polder, by their moderating role, and secondly, by the great number of fluviatile limans. To the west, Danubian Dobrudja dominates the Ialomiţa Pond and the Braila Pond through a steep slope cut in Sarmatian limestones and Pliocene deposits, made uneven by $90 \mathrm{~m}-120 \mathrm{~m}$. From a morphological and morphometrical perspective, the values of this subunit decreased from the east towards the west, and from the south towards the north, from around $100 \mathrm{~m}-170 \mathrm{~m}$ to the contact with the continental Dobrudja, to $10 \mathrm{~m}-20$ $\mathrm{m}$ at the level of the lacustrine complexes and of the Danube Floodplain. The strongest altimetric contrasts are found in the southern side. For this reason, the most interesting piping forms are developed only in the sector of contact with high slopes. In this case, a border modelling and a marginal piping emerged, specific only to the Danubian slopes (Fig. 2).

\section{Landforms and microlandforms}

Landforms have a mainly tabular character caused by a relatively uniform and homogeneous lithology. In exchange, the petrographic nature nuanced the microrelief (Table 2). The slightly wavy plaque of the Sarmatian limestones covered certain structural characters included within the relief, through quasihorizontal interfluves of $100 \mathrm{~m}-130 \mathrm{~m}$. The interfluves were significantly fragmented by the system of allochthonous and autochthonous valleys, continuing toward the Danube. The valleys had a subsequent character in the middle sector, and a consequent character in the lower sector. The relief energy of the valleys ranged between $100 \mathrm{~m}$ and $120 \mathrm{~m}$. On the bottom of the valleys, there were alternating narrow sectors that may include interlocked meanders, but also wider bassinet-shaped sectors. The general flow direction in the valleys was SouthEast NorthWest (SE-NW), which explains their initially epigenetic and subsequently, antecedent origin.

The most important and particular relief level is represented by the Romanian (Levantine) terrace mentioned by C. Bratescu (1928) for the first time, and then, by P. Cotet (1969). The forehead of the terrace was steep and affected by intense geomorphological processes specific to the semi-arid climate, and to the loess or loess-like deposits. This general morphological background - where levelling surfaces provided the specificity of the Danubian Dobrudja relief - is also characteristic (secondarily) to minor relief landforms. The broad extension of very thick and lowly inclined loess-like deposits, the existence of fossil soils and of clayey bands with the role of impermeable horizons, the reduced cohesion of loesslike deposits, and the low and close base level, conditioned the emergence of a 
wide palette of microforms. Through their density and size, they contributed to the individualization of this region. This study includes only the landforms featuring special characteristics, different from those within the loessoid areas around the Globe.

Table 2 - Microlandforms in the loess and loess-like deposits of Dobrudja

\begin{tabular}{|c|c|c|c|}
\hline Microlandform & Location & $\begin{array}{c}\text { Main generating } \\
\text { process }\end{array}$ & Typical dimensions \\
\hline Pipe & Plateau & Piping & $0.2-0.5 \mathrm{~m}$ across \\
\hline Tunnel & $\begin{array}{l}\text { Underground } \\
\text { erosion }\end{array}$ & Piping & 0.5-2.0 $\mathrm{m}$ high \\
\hline Clastic dolines & Plateau margins & Piping & 5-10 m diameter \\
\hline Piping alluvial fans & $\begin{array}{l}\text { At outlets of } \\
\text { resurgences }\end{array}$ & Piping & 5-15 m lenght \\
\hline Piping abysses & Plateau margins & Piping & $\begin{array}{c}10-15 \text { m wide, } 20 \mathrm{~m} \\
\text { deep }\end{array}$ \\
\hline Drapes & Steep slopes & $\begin{array}{c}\text { Gully } \\
\text { erosion/piping }\end{array}$ & $15-20 \mathrm{~m}$ lenght \\
\hline $\begin{array}{l}\text { Clastic micro-waterfalls } \\
\text { with clastic micro- } \\
\text { cauldrons }\end{array}$ & Steep slope & $\begin{array}{c}\text { Gully } \\
\text { erosion/piping }\end{array}$ & $0.7-1.3 \mathrm{~m}$ high \\
\hline $\begin{array}{l}\text { Hanging valleys } \\
\text { (valleuses) }\end{array}$ & Plateau margins & $\begin{array}{c}\text { Gully } \\
\text { erosion/piping }\end{array}$ & 5-20 m lenght \\
\hline
\end{tabular}

A very important role in the current landform modelling is played by the torrential waters, specific to Dobrudja. The emergence and development of the torrential bodies, mostly occurred in former forested or pasture areas, altered by anthropic intervention. The degradation of natural vegetation was the trigger for the most intense areolar and linear erosion processes. The change in the amount of water within the soil led to a reduction of flows, and to the disappearance of certain springs within the valleys. The accelerated deposition of alluvia, determined the intense valley aggradation; therefore, the distance between the minor riverbed and the phreatic nappe increased. This led to a phenomenon called the "alluvial drowning" of the valleys. In this case, small valleys with a permanent character have dried out, or they are in the process of drying out (Romanescu et al., 2010). Though, the torrentiality of water is less visible through erosion, it becomes really dangerous through alluvial deposition. Hence, most valleys are practically drowned in materials that have fallen off interfluves. Aggradation may even exceed several $\mathrm{cm} /$ year (Romanescu, 1995). The most visible clogging phenomenon is dominant 
in the upstream, sectors of lacustrine cuvettes, where the main valleys discharge into lakes and where veritable micro-deltas or large alluvial fans are created.

The basic process of minor landforms within Danubian Dobrudja is represented by piping; the secondary process consists in karst (in the substrate). This process set in motion solid particles under the pressure exerted by groundwater flows. Piping represents the mechanical dislocation and transport of fine particles, performed by rapid temporary flows of groundwaters, within friable rocks. They acquire a typical character only on top of the phreatic nappe or at its level, mainly during heavy rains (Romanescu et al., 2010). Because it is a subversion process due to groundwater circulation, it is part of the so-called infiltration relief. In this process, water only exerts its mechanical force (Tufescu, 1966).

While in motion, groundwater leads to banks and bevel slides, settlings, to the construction of underground cavities, leading to the emergence of surface negative forms, such as piping cones of microforms specific to this pseudokarst: typical clastic dolines, solution clastic dolines, collapse clastic dolines, and so on (Fig. 3). The evolved clastokarst forms have this shape because they develop in the

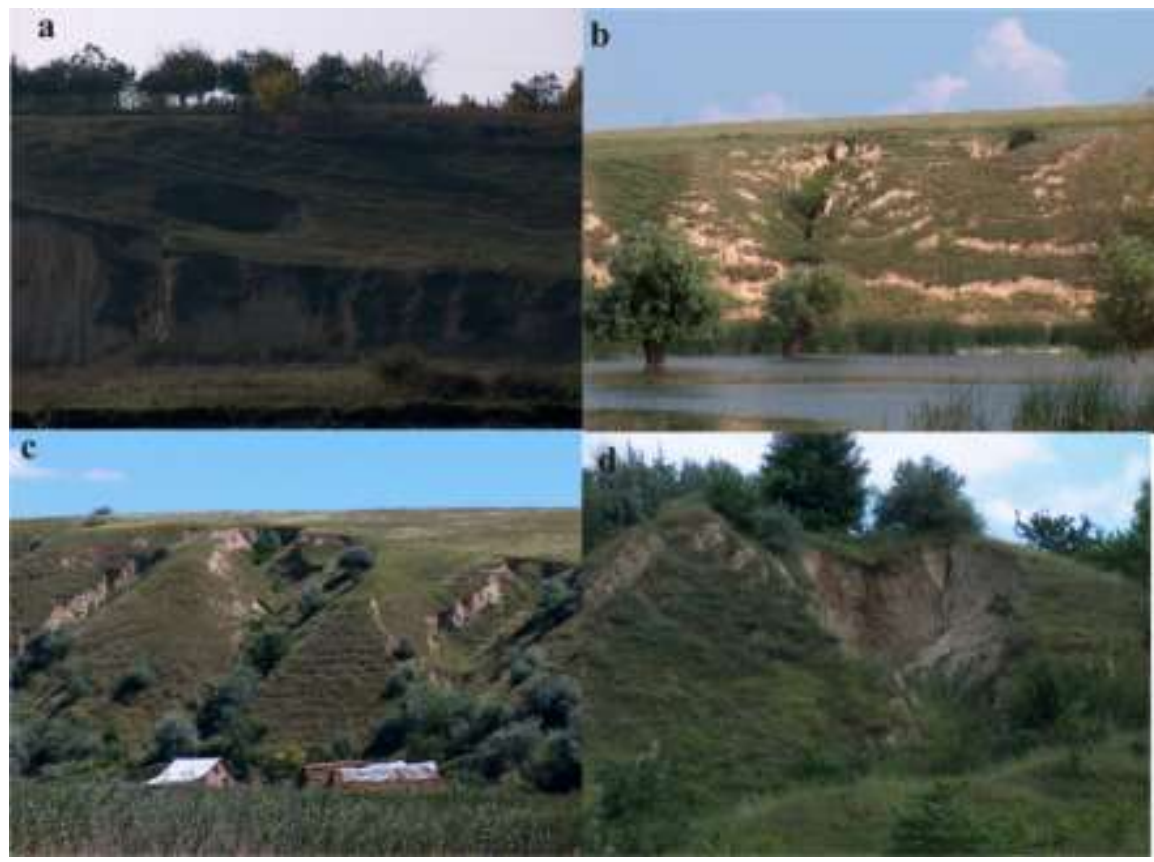

Fig. 3 - Piping dolines (clastic dolines): a. incipient (active or typical); b. evolved; c. solution; d. collapse (senility study) (Vederoasa - a; Mineri - b; Daeni - c; Luncavita - d) 
marginal sector of the plateau, with steep slopes and low base level. The elimination of water at the foot of the slope occurs at a small distance from the infiltration spot (from a few meters to a few dozen meters). The development of the piping process requires certain conditions, such as the existence of porous, permeable rocks, such as loess or loess-like deposits. The same forms can also emerge in fine marshy sands, dusty clayey sands, or even sandy loam. Another condition is the existence of a climate in a droughty season, even arid to some extent. This climate is closely related to the discontinuous draining of waters situated at the base of loess, which thus, circulate as underground streams or torrents or as surface torrents, which discharge into a waterfall (clastic microwaterfall) (Fig. 4). The existence of steep banks and the spasmodic character of the flow, makes the torrential water, fall on several levels, thus, forming clastic microcauldrons (Fig. 4).

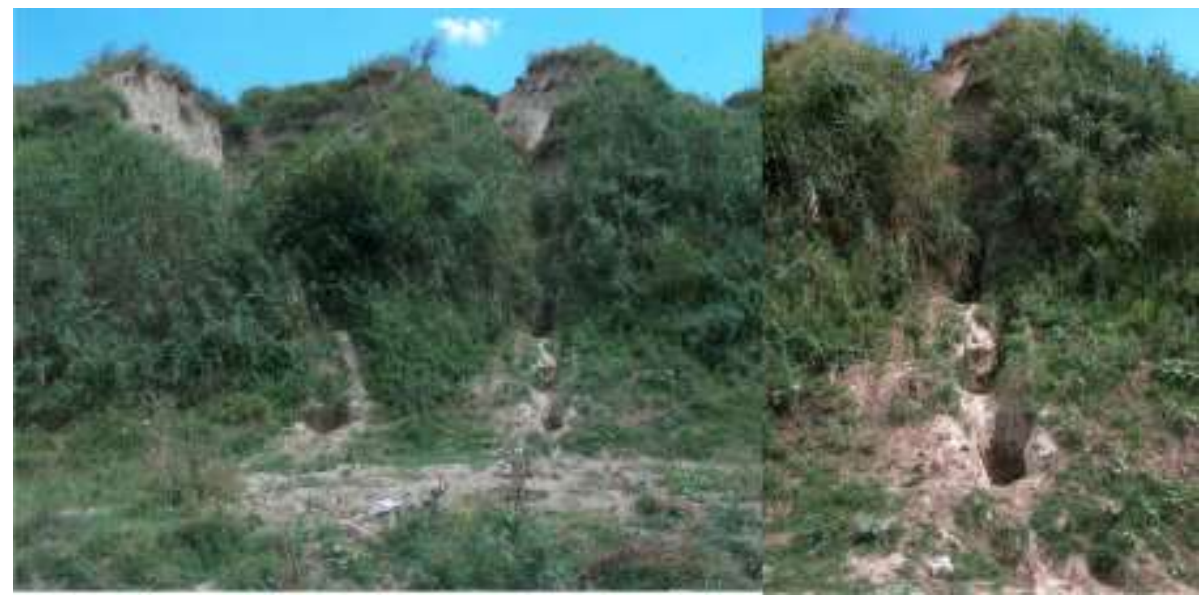

Fig. 4 - Clastic micro-fall and the western sector of the Dobrudja Plateau (Frecatei)

Loess and loess-like deposits (formations), due on one hand to specific porosity and on the other to the narrow vertical channels, provide the possibility of maximum infiltration of meteoric water on the vertical (on the horizontal it is reduced) that occurs in marginal sectors. These phenomena explain the characteristic shaping of these rocks on horizontal planes, as well as the possibility for certain narrow column separated from the rest of the bank to remain in a vertical position for a while, which provides a shape similar to limestone banks, to the loess banks. Loess-like deposits are extremely sensitive to the action of water, which levigates and dissolves the limestone particles. In this case, loess becomes 
moist, tender, and loses its cohesion, thus settling and collapsing into vertical fissures.

In the conditions of a drought season specific to the temperate continental climate with excessive nuances, such as the one of Dobrudja, the phreatic water records a temporary draining. In this case, it forms veritable underground torrents that flow through the rock pores and through fissures, thus, acquiring various inclinations and speeds. On high speeds and pressures, the water of underground torrents becomes turbulent, and it also carries solid particles found along its way. Therefore, the underground current exerts a genuine erosive action upon the areas it crosses, thus, creating cavities which gradually enlarges and turns into piping tunnels that discharge into the base of the scarp as clastic resurgences (pseudoresurgences, intermittent karst springs), and which end in piping alluvial fans (Figs. 5, 6) (Romanescu, 1995). These small alluvial fans do not have an obvious

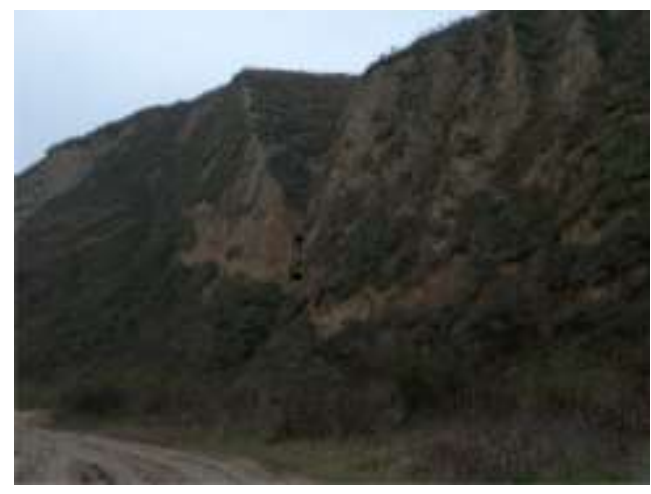

Fig. 5 - Hanging valley and clastic resurgence (intermittent karst spring or pseudoresurgence) (Ostrov)

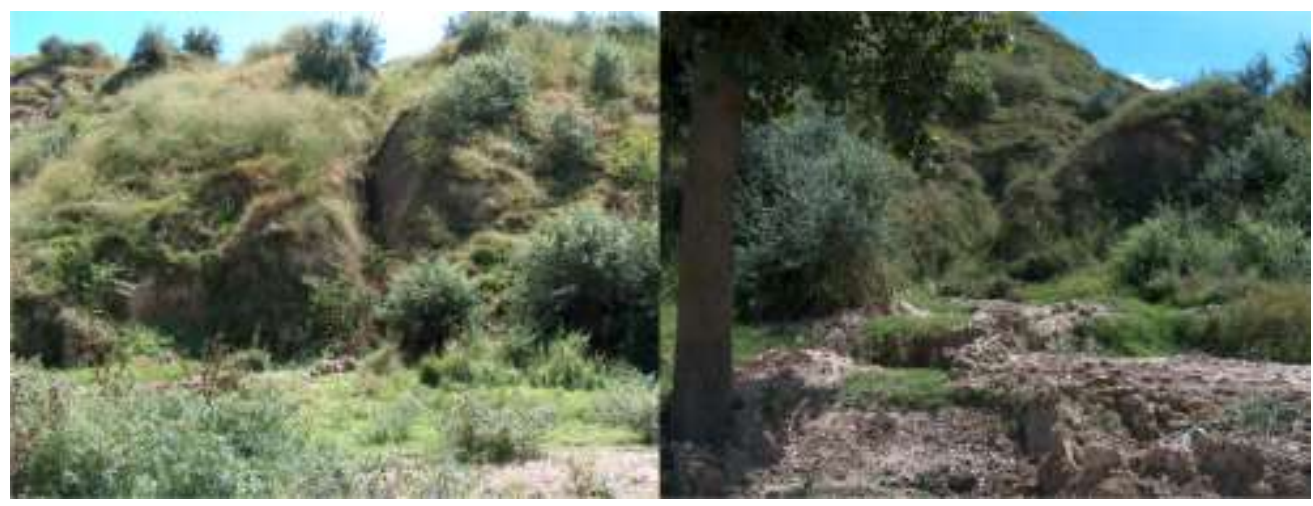

Fig. 6 - Piping alluvial fan (Ostrov-Peceneaga) 
granulometric differentiation. Rarely, can they even form - through coalescence proluvial micro-glacis (between the localities of Malcoci and Nufaru in the north of the Dobrudja Plateau). The resurgences and exurgences in the Romanian territory are known as izbucuri (intermittent springs), specific to karst relief. Thus, on loess and loess-like deposits, they may be called intermittent karst springs.

Because the circulation of underground current is only possible through a correlation with the normal atmospheric pressure (on the planes of vertical fissures), absorption leads to the emergence of vertical vents that look like air holes. In this case, piping vents and cones emerge. When the loessoid deposit is very thick, the piping structure is significant. In this case, enlarged vents turn into piping abysses that may exceed $10 \mathrm{~m}-15 \mathrm{~m}$ in width, and that may reach $20 \mathrm{~m}$ in depth. At their base, there are often loess needles $20 \mathrm{~m}-30 \mathrm{~cm}$ thick and $10 \mathrm{~m}-12$ $\mathrm{m}$, high. Tunnel mouths can reach even $2 \mathrm{~m}$ in height; some of them can be situated on the slopes too, not necessarily at their base. Repeated collapses may form collapse banks, such as a collapse glacis (Fig. 7), unique in the Dobrudjan clastokarstic relief. Proluvial clastic glacis may also emerge; they are different from piping ones because they are as a result of superficial torrent erosion (Fig. 8).

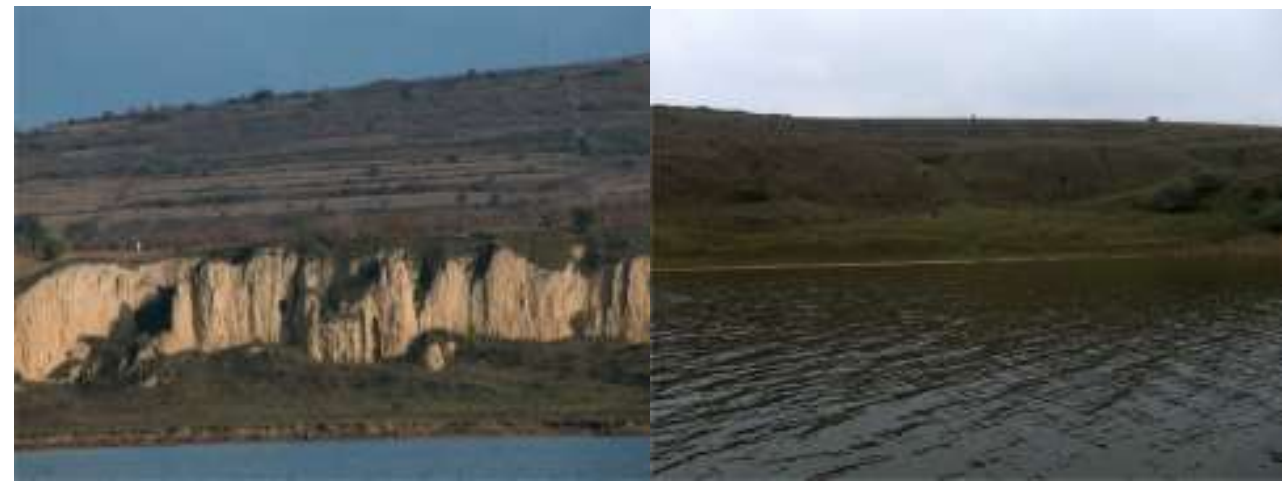

Fig. 7 - Collapse glacis (Oltina)

Fig. 8 - Proluvial glacis (Vederoasa)

The emergence of piping forms on a certain alignment, leads to the creation of piping complexes, such as piping precipices and valleys. Precipices result from the coalescence of several cones within a row, by the collapse of bridges between them down to the level of the underground tunnel. The piping precipice acquires the appearance of a gully with vertical slopes, most often closed at both ends. A piping structure comprises, in the upper side, a cone-shaped gap with a mouth measuring 2 m-3 m or even more, and a depth around half the diameter, which resulted from minor lateral collapses. The resulting piping cone is similar to the dolines of the 
clastic relief (clastic dolines). The orifice at the bottom of the cone continues on the vertical with a narrow channel, which crosses almost the entire thickness of the loess layer, where most of the piping process takes place. The piping vent played the role of soakaway because, like an air hole, it connects to the spot where the air current circulates at the base of the loess. Usually, such cones are not isolated, but we encountered a row of cones and vents aligned along the circulation currents of the groundwaters. At the base of loess, their erosion created piping tunnels which looked like miniature caves, around $0.5 \mathrm{~m}-2 \mathrm{~m}$ high. Because of rock friability, they collapsed rapidly and they contributed to the transport of solid materials at the base of slopes, on land, or directly in lakes (Fig. 9a). The maturity stage characterized by intense activity, is followed by the senility stage, when the specific forms disappear (Fig. 9b). At the edge of the lakes with abrupt walls, clogging is rapid, which may even lead to a slightly submerged glacis. When clastic dolines merge, they form a (piping) draped border, with hillocks of various sizes (Fig. 10). On steep slopes with a mainly vertical runoff, clastokarstic curtains (drapes) are formed, caused by differential erosion (Fig. 11).

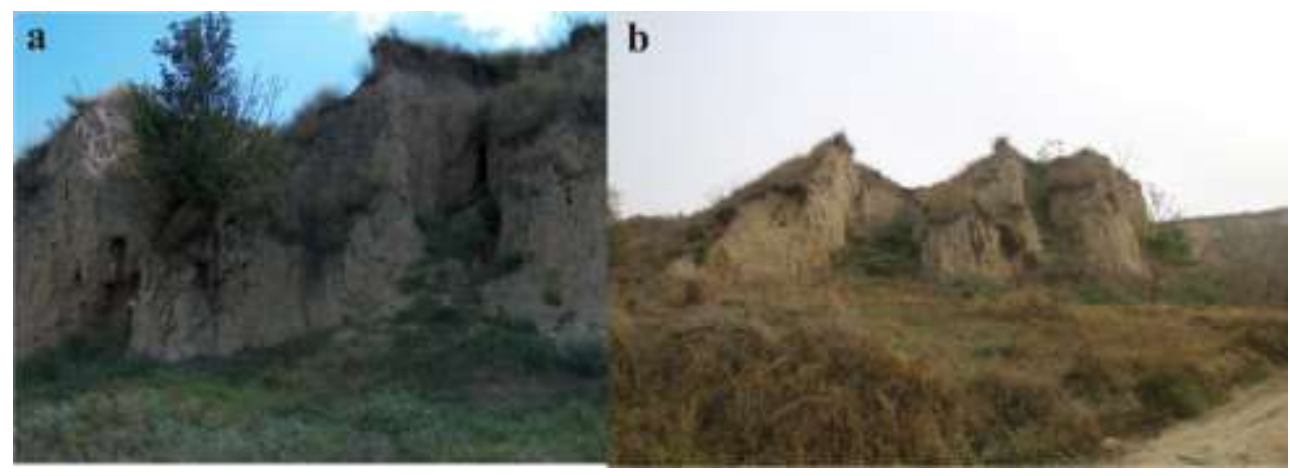

Fig. 9 - Border piping complex: a. active; b. evolved (Luncavita-Rachelu)

The depth of piping processes depends, like in the case of the karstic erosion, on the lower limit of the rock deposits. If the loess is on a harder rock like the Sarmatian limestone, all piping processes stop at this level, though it is much higher than the Danube level (base of local erosion). The most common forms are represented by hanging valleys (valleuses), formed when the bank erosion was high (Fig. 12). If loess-like deposits are on relatively soft rocks, such as clays, gravels, or loam, piping processes stop at these surfaces, due to a change in the characteristics of the rock for water circulation purposes. Piping processes stop at the level of the Sarmation limestone. 
Buried soil bands (paleosols) introduce a discontinuity in the development of piping forms. In this case, small collapse levels emerge, which created inclined planes. Piping comprises two basic levels: general - represented by the lacustrine surface or the water stream; local - in our case, the level of tougher rocks within the substrate. The basic piping process is strongly influenced by the oscillations of the phreatic water levels. When such levels rise, the piping process is slower, and when it lowers, the process accelerates.

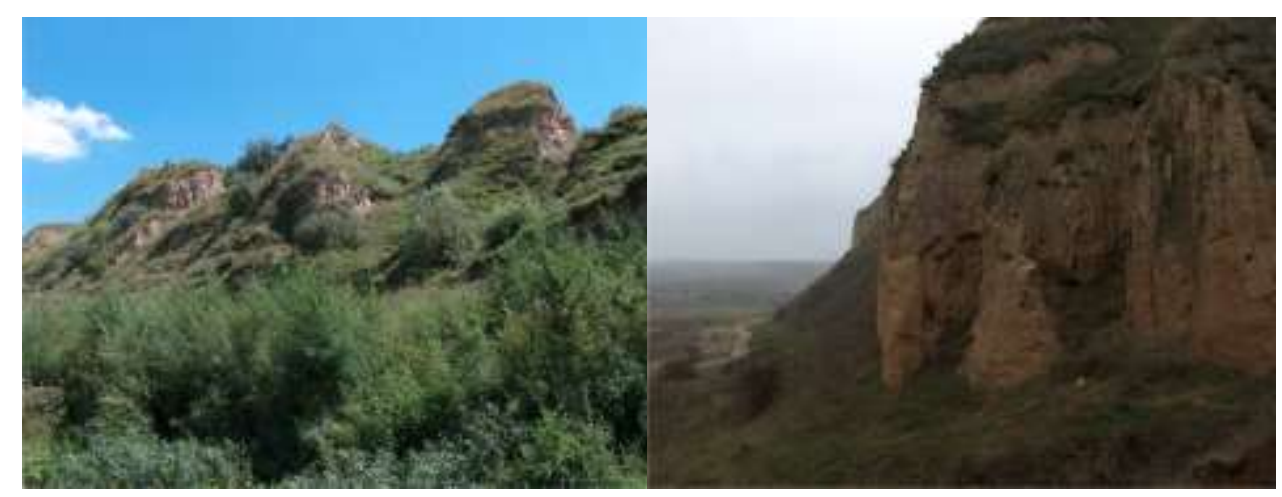

Fig. 10 - Piping drape (Peceneaga)

Fig. 11 - Clastockarstic curtains (drapes) in Dobrudjan loess (Ostrov)

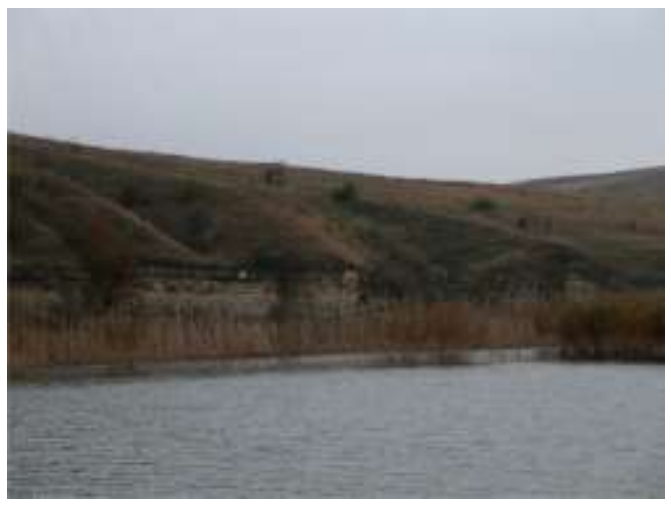

Fig. 12 - Hanging valleys (valleuses), on discordant structure (Oltina)

Piping is distinct among the denudational agents, because of its specific landforms and characteristic evolution, generated by a well-individualized agent (the mechanical force of groundwater flow). When other denudational agents exert their action too, associated forms such as collapse steps emerge, which cannot be 
mistaken with piping steps. When another agent takes over the forms created by piping, such as surface run-offs, it degrades them, transforms them, and provides a different geomorphology to the entire landscape (loessoid geolandscape). Groundwater is a complete agent, which displaces, transports, deposits, and finally levels, and generally, lowers landforms, implicitly (Tufescu, 1966).

Piping contributes to the destruction and withdrawal of the loess banks and loess-like deposits, getting the field ready for this action on an extended area behind the scarp, by deepening piping tunnels, by local collapses and settlements that cause underground deformations and cracks, or even destruction to misplaced constructions. Clastic gullies (Fig. 13) eroded in a more humid climate - with a more significant runoff than the current one - have led to the creation of canyon valleys, with steep walls and flat bottom (Fig. 14). Evolved piping valleys delimit large hillocks (Fig. 15).

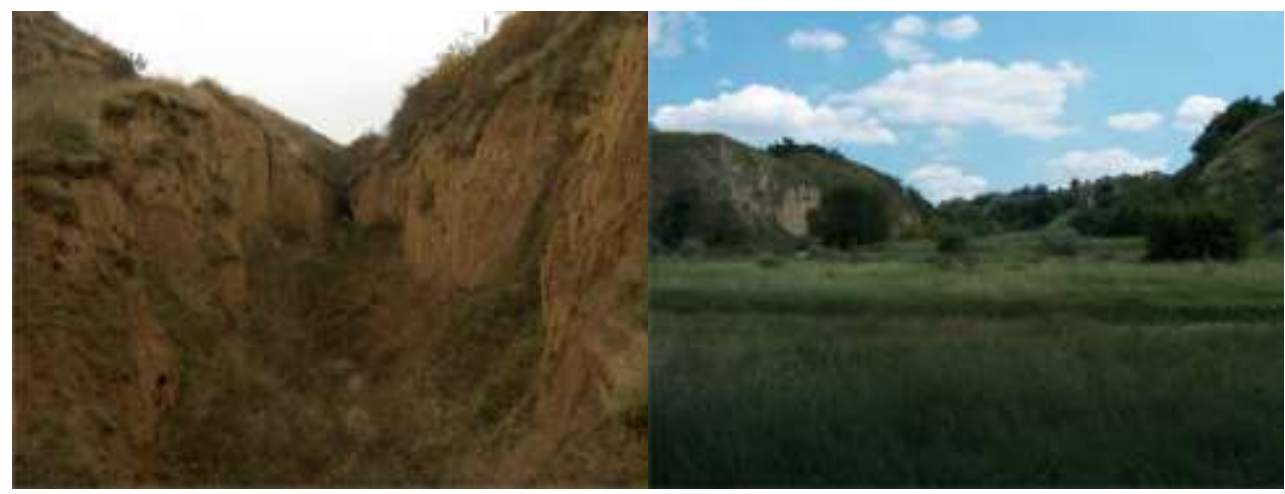

Fig. 13 - Clastic gully and piping supply $\quad$ Fig. 14 - Piping canyon (Garliciu-Daeni) in the southeast of Dobrudja (Galita)

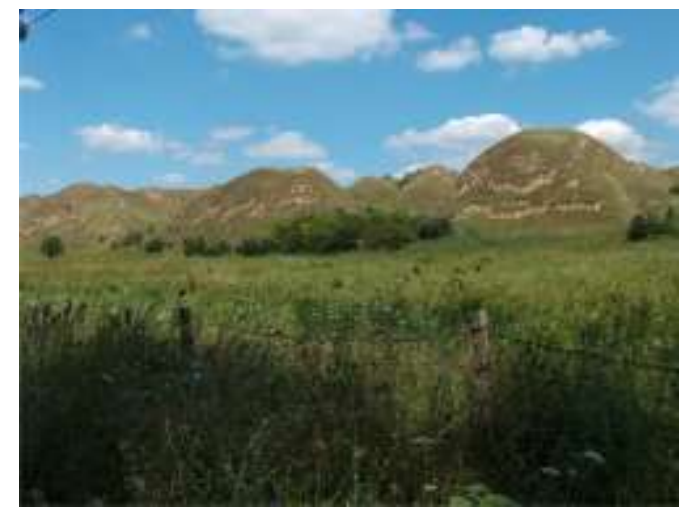

Fig. 15 - Piping valleys and hillocks (Garliciu-Daeni) 


\section{Conclusions}

Loess and loess-like deposits in Dobrudja were deposited in the last three glaciations of the Quaternary: Mindel, Riss, and Würm. The existence of fossil soils-alongside other factors-induces a runoff pattern change in the deposits. High porosity of the loess-like deposits, massive deforestations, the use of fields for agriculture, the use of pastures for pasturing (excessive pasturing), and so on, leads to an acceleration of superficial and underground erosion processes. The complex forms and microforms specific to loess and loess-like deposits, creates a specific landscape: loess-scape. Consequently, processes and landforms developed on loess and loess-like deposits depend on the climate and the nature of modelled material. Secondarily, the anthropic activity is also worth taking into account. The important deposit thickness $(50 \mathrm{~m})$ and the horst shape of Dobrudja, led to the development of a loessoid relief specific to the marginal (border) areas on the Danube terrace, where slopes are elevated. The intermittent runoff determined by heavy rains that occur frequently during the summer, when vegetation is scarce because of drought, makes the landforms take different shapes compared to those in other regions of the Globe. The particular morphology of the minor landforms has led to a renaming and to the identification of new forms: clastic dolines (incipient, evolved, solution, collapse), clastic micro-falls, clastic micro-cauldrons, clastic resurgences (intermittent karst springs or pseudo-resurgences), piping alluvial fans, collapse glacis, clastockarstic curtains (drapes), clastic gullies, and so on.

Acknowledgments: Our sincerest gratitude goes to the Geo-archaeology Laboratory within the Faculty of Geography and Geology from the "Alexandru Ioan Cuza" University of Iasi, which provided the equipment and processed the data. This study was supported by the Partnership in Priority Domains project PN-II-PTPCCA-2013-4-2234 no. 314/2014 of the Romanian National Research Council, Nondestructive approaches to complex archaeological sites. An integrated applied research model for cultural heritage management - arheoinvest.uaic.ro/research/prospect.

\section{References}

Antonov, D. (2003), Assessment of loess composition and structure in connection with radioactive waste disposal 50 years University of Mining and Geology. "St. Ivan Rilski” Annual, Geology and Geophysics, Sofia, 46(I):321-326.

Balescu, S., Lamothe, M., Panaiotu, C.E., Panaiotu, C.G. (2010) La chronologie IRSL des séquences loessiques de l'est de la Roumanie. Quaternaire, 21(2): 115-126.

Bratescu, C. (1928), Pamantul Dobrogii. - Volum jubiliar „Dobrogea”, Bucuresti, 3-66.

Buggle, B., Hambach, U., Glaser, B., Gerasimenko, N., Marković, S., Glaser, I., Zöller, L. (2009), Stratigraphy, and spatial and temporal paleoclimatic trends in 
Southeastern/Eastern European loess-paleosol sequences. Quaternary International, 196:86-106.

Castillo, C., Gómez, J.A. (2016), A century of gully erosion research: Urgency, complexity and study approaches. Earth-Science Reviews, 160:300-319.

Conea, A. (1970), Formaţiuni cuaternare in Dobrogea. Editura Academiei Romane, Bucuresti.

Constantin, D., Begy, R., Vasiliniuc, S., Panaiotu, C., Necula, C., Codrea, V., TimarGabor, A. (2013), High resolution OSL dating of the Costinesti section Romania using fine and coarse quartz. Quaternary International, 334-335:20-29.

Cotet, P. (1969), Dobrogea de Sud - geneza si evolutie. Studii geografice asupra Dobrogii, Bucuresti, 1:7-19.

Florea, N. (2010), Loess was formed, but not sedimented. Rev. Roum. Géogr./Rom. Journ. Geogr., 54(2):159-169.

Frincu, M., Dumitrache, C. (2014), Geological caracterization of loessoid soils from Romania. Journal of Young Scientist, II:39-44.

Ghenea, C., Radan, S.C. (1993), New data on the age of the loess in Dobrogea. Rom. J. Stratigr., 75:133-137.

Ionesi, L. (1994), Geologia unitatilor de platforma si a orogenului nord-dobrogean. Editura Tehnica, Bucuresti.

Jordanova, D., Petersen, N. (1999), Paleoclimatic record from a loess - soil profile in northeastern Bulgaria - II. Correlation with global climatic events during the Pleistocene. Geophys. J. Int., 138:533-540.

Jordanova, D., Hus Geeraerts, J.R. (2007), Palaeoclimatic implications of the magnetic record from loess/palaeosol sequence Viatovo (NE Bulgaria). Geophys. J. Int., 171:1036-1047.

Kuzila, M.S. (1995), Identification of multiple loess units within modern soils of Clay County, Nebraska. Geoderma, 65:45-57.

Lăcătușu, R., Lungu, M., Aldea, M. M., Lăcătușu, R., Stroe, V.M., Rizea, N., Lazar, R. (2010), Selenium in rock-soil system in the South-Eastern part of Romania. Journal of Agricultural Sciences, 42(4):199-204.

Leger, M. (1990), Loess landforms. Quaternary International, 7-8:53-61.

Li, Z., Zhang, Y., Zhu, Q., He, Y., Uao, W. (2015), Assessment of bank gully development and vegetation coverage on the Chinese Loess Plateau. Geomorphology, 228(1): 462469. Doi:10.1016/j.geomorph.2014.10.005.

Li, Z., Zhang, Y., Zhu, Q., Yang, S., Li, H., Ma, H. (2016), A gully erosion assessmentmodel for the Chinese Loess Plateau based on changes in gully length and area. Catena, 148:195-203. Doi.org/10.1016/j.catena.2016.04.018.

Muhs, D.R., McGeehin, J.P., Beann, J., Fisher, E. (2004), Holocene loess deposition and soil formation as competing processes, Matanuska Valley, southern Alaska. Quaternary Research, 61:265-276.

Necula, C., Dimofte, D., Panaiotu, C. (2015), Rock magnetism of a loess-palaeosol sequence from the western Black Sea shore (Romania). Geophysical Journal International, 1733-1748. 
Pye, K. (1996), The nature, origin and accumulation of loess. Quaternary Science Reviews, $14: 653-667$.

Radan, S.C., Ghenea, C., Radan, M. (1990), Palaeomagnetic investigation of Pleistocene formations in Romania and their magnetostratigraphic significance. In: Wiegank, F. (ed.). Geomagnetic Field in Quaternary. Veröffentlichung 62, Zentralinstitut für Physik der Erde, Akademie der Wissenschaften der DDR, Potsdam, 115-120.

Radan, A.C. (2012), Towards a synopsis of dating the loess from the Romanian Plain and Dobrogea: authors and methods through time. Geo-Eco-Marina, 18:153-172.

Romanescu, G. (1995), Consideratii geomorfologice preliminare asupra sectorului central-nordic al Dealurilor Tulcene. Lucr. Seminarului Geografic "Dimitrie Cantemir", 11-12:17-28.

Romanescu, G., Cojocaru, I. (2010), Hydrogeological considerations on the western sector of the Danube Delta - a case study for the Caraorman and Saraturile fluvialmarine levees (with similarities for the Letea levee). Environmental Engineering and Management Journal, 9(6):795-806.

Romanescu, G., Dinu, C., Radu, A., Torok, L. (2010), Ecologic characterization of the fluviatile limans in the south-west Dobrudja and their economic implications (Romania). Carpathian Journal of Earth and Environmental Sciences, 5(2):25-38.

Romanescu, G. (2013), Geoarchaeology of the ancient and medieval Danube Delta: Modeling environmental and historical changes. A review. Quaternary International, 293:231-244.

Romanescu, G. (2014), The catchment area of the Milesian colony of Histria, within the Razim-Sinoie lagoon complex (Romania): hydro-geomorphologic, economic and geopolitical implications. Area, 46(3):320-327.

Romanescu, G., Sandu, I., Stoleriu, C., Sandu, I.G. (2014), Water Resources in Romania and Their Quality in the Main Lacustrine Basins. Rev. Chim. (Bucharest), 63(3):344349.

Romanescu, G., Bounegru, O., Stoleriu, C., Mihu-Pintilie, A., Nicu, C., Enea, A., Stan, O. (2015), The ancient legendary island of PEUCE - myth or reality? Journal of Arechaeological Science, 53:521-535.

Rozycki, St.Zb. (1967), Le sens des vents portant la poussière de loess, a la lumière de l'analyse des formes d'accumulation du loess en Bulgarie e ten Europe Centrale. Revue de Géomorphologie Dynamique, 17(1):1-9.

Su, X., Nilsson, C., Pilotto, F., Liu, S., Shi, S., Zeng, B. (2017), Soil erosion and deposition in the new shorelines of the Three Gorges Reservoir. Science of the Total Environment, 599-600:1485-1492.

Tufescu, V. (1966), Modelarea naturala a reliefului si eroziunea accelerata. Editura Academiei Romane. Bucuresti.

Wang, H.B., Zhou, B., Wu, S.R., Shi, J.S., Li, B. (2011), Characteristic analysis of largescale loess landslides: a case study in Baoji City of Loess Plateau of Northwest China. Natural Hazards and Earth System Sciences, 11:1829-1837.

Zhu, T.X., Luk, S.H., Cai, Q.G. (2002), Tunnel erosion and sediment production in the hilly loess region, North China. Journal of Hydrology, 257:78-90. 
Zhongchen, L., Baoyin, Y. (1995), A critic analysis of environmental evolution in the loess-plateau area. Journal of Environmental Sciences, 7(3):283-288.

* * *. (2015), acinetnathaz.net/wp-content/uploads/2015/12/LHA-Tessaloniki-May-2015Carmen-P4.pdf. 